\title{
Concentration, Soil-To-Plant Transfer Factor Determination of Heavy Metals in Udu Area of Delta State, Nigeria
}

\author{
M. A. Balogun ${ }^{1 *}$ and M. O. Money-Irubor ${ }^{2}$ \\ ${ }^{1}$ Department of Chemistry, College of Education, Warri, Delta State. \\ ${ }^{2}$ Department of Integrated Science, College of Education, Warri, Delta State. \\ *Corresponding author: Balogunadebayo2007@gmail.com \\ Received 06 November 2020; accepted 15February 2021, published online 30 March 2021
}

\begin{abstract}
ABSRACT
Heavy metals in varied concentrations are employed in the production of steel of different grades. Silver, cadmium, cobalt, chromium, and copper are of great importance in achieving this. They are part of the main ingredients in the production processes, which in most cases determines steel grades. The location of an integrated steel plant within Udu community of Delta State resulted in the pollution of the soil of the surrounding communities, most of which are involved in farming and fishing activities. This necessitated the transfer of these heavy metals from polluted soils into edible plants. These were mainly as a result of discharges of effluents, smoke and particulates from stack during production into the soils of the surrounding communities and finally into some edible plants; that are consumed by the communities as vegetables. Soil and leaf samples were collected from six different towns or communities in Udu. The towns are Ujevwu, Aladja, Ovwian, Ekete Inland, Orhuwhorun and Otor-Udu; and the heavy metals analysed are Ag, Cd, Co, $\mathrm{Cr}, \mathrm{Cu}$ and $\mathrm{Fe}$. These samples were digested using USEPA Method 3050B and the heavy metals were determined using atomic absorption spectrophotometer (AAS). Results obtained showed the following range for transfer factors (TF) in three different edible plants; which are pumpkin plant (Telfaira occidentalis), bitter leaf plant (Vernonia amygdalina) and scent leaf plant (Occinium gratissimum). The range of values obtained for the transfer factors are- Ag: 4.48-196.45; Cd: 44.52-212.79; Co: 0.03-0.46; Cr: 0.38-3.37; Cu: 21.76-102.95 and Fe: 2.85-14.40. For the six sample sites, generally, the values are in the order: $\mathrm{Cd}>\mathrm{Ag}>$ $\mathrm{Cu}>\mathrm{Fe}>\mathrm{Cr}>\mathrm{Co}$. Result interpretation shows some level of contamination when compared to recommended standard of these heavy metals in plants. The effect of which can be devastating in the future if not checked.
\end{abstract}

Keywords: Pollution, industrialisation, effluent, transfer factor.

\section{INTRODUCTION}

It is of necessity that humans must survive, have shelter and other basic needs. To achieve this, there has to be series of activities. Among this are farming, trading and most importantly today, industrial activities. This brought about industrialisation. It is known all over the world that industrialisation is a necessary tool for economic development and sustenance. Associated with this positively are job opportunities, increased economic activities, societal and community gains, to mention but a few. While the negative consequences include pollution of the environment, such as air, water and soil. This results in degradation of immediate constituents and vegetation. A number of factors have been reported to be responsible for the development, distribution and characterisation of pollutants in soils and plants. Some of these factors include, apart from industrialisation, the intensification of agriculture which involves the use of fertilizers, herbicides, fungicides and pesticides. Other factors include certain environmental conditions such as temperature. Also, the characteristics of both soils and plants in the uptake, retention and distribution of pollutants are significant factors in this regard $[3,11]$.

Industrialisation has become a necessary tool for human survival and sustenance; however, not without consequences. Some of which is alternation of the environment in various ways resulting in abundant release of both visible and non-visible pollutants [7]. The establishment of a mega steel plant at Ovwian-Aladja served as a form of industrial revolution in Udu area of Delta State. It generated a lot of employment and small scale industrial opportunities. However, the negative consequence is the pollution of the surrounding communities due to these industrial activities. Heavy metals such as iron, copper, zinc 
and nickel are important for proper functioning of biological systems and their deficiency or excess could lead to a number of disorders. Food chain contamination by heavy metals has become a burning issue in recent years because of their potential accumulation in biosystems through industrial discharges and contaminated water, soil and air. The main sources of heavy metals to vegetable crops are their growth media, which consist of soil, air and nutrient solutions; from which these heavy metals are taken up by the roots or foliage [8].

However, it is becoming more pronounced that these industries are becoming the main sources of pollutants to the communities living around them. This is because most of the required standard operation procedures (SOP) are no longer followed; apart from the fact that most of the equipment are obsolete and dilapidated. Such neglect caused some of the well-known world documented industrial accidents, such as the Minamata Bay mercury poisoning in late 1953 in South Western Kyushu (Japan) and the explosion at Union Carbide's pesticide plant in Bhopal (India) which resulted in death of over 2,000 people, with over 50,000 with different ailments [13]. Such may become the case of Delta Steel Company (DSC) at Ovwian-Aladja in Delta State, where most of the equipment have become obsolete and are not working according to the required standards. Untreated or half-treated effluents are discharged into river without any respect to required regulations. The contamination or pollution levels of the various metals in either soil or plant is best summarized in Table 1, which show clearly that some metals at certain levels contaminate the soil or become dangerous in plant [1]. This is more devastating when in plants, since these plants end up consumed by humans or other living organisms.

Table 1: Concentrations and Critical Concentrations of Heavy Metals in Plants and Soils

\begin{tabular}{cccccc}
\hline Metals & $\begin{array}{c}\text { Non Plants } \\
\text { Concentrations } \\
(\mathbf{m g} / \mathbf{k g})\end{array}$ & $\begin{array}{c}\text { Critical Plants } \\
\text { Concentrations } \\
\mathbf{A}(\mathbf{m g} / \mathbf{k g})\end{array}$ & $\begin{array}{c}\text { Critical Plants } \\
\text { Concentrations } \\
\mathbf{B}(\mathbf{m g} / \mathbf{k g})\end{array}$ & $\begin{array}{c}\text { Normal Soils } \\
\text { Concentrations } \\
(\mathbf{m g} / \mathbf{k g})\end{array}$ & $\begin{array}{c}\text { Critical Soils } \\
\text { Concentrations } \\
(\mathbf{m g} / \mathbf{k g})\end{array}$ \\
\hline $\mathrm{As}$ & $0.02-7$ & $5-20$ & $1-20$ & $0.1-40$ & $20-50$ \\
$\mathrm{Cd}$ & $0.1-2.4$ & $5-30$ & $4-200$ & $0.01-2.0$ & $03-\mathrm{Aug}$ \\
$\mathrm{Co}$ & $0.02-1$ & $15-50$ & $4-40$ & $0.5-65$ & $25-50$ \\
$\mathrm{Cr}$ & $0.03-14$ & $5-30$ & $2-18$ & $5-1500$ & $75-100$ \\
$\mathrm{Cu}$ & $5-20$ & $20-100$ & $5-64$ & $2-250$ & $60-125$ \\
$\mathrm{Hg}$ & $0.005-0.17$ & $1-3$ & $1-8$ & $0.01-0.5$ & $0.3-5$ \\
$\mathrm{Mn}$ & $1-20$ & $300-500$ & $100-700$ & $20-10000$ & $1500-3000$ \\
$\mathrm{Mo}$ & $0.03-5$ & $10-50$ & - & $0.1-40$ & $02-\mathrm{Oct}$ \\
$\mathrm{Ni}$ & $0.02-5$ & $1-100$ & $8-220$ & $2-750$ & 100 \\
$\mathrm{~Pb}$ & $0.02-20$ & $30-300$ & - & Feb-30 & $100-400$ \\
$\mathrm{Sb}$ & $0.0001-0.2$ & - & $1-2$ & $0.2-10$ & $05-\mathrm{Oct}$ \\
$\mathrm{Se}$ & $0.001-2$ & $5-30$ & $3-40$ & $0.1-5$ & $5-10$ \\
$\mathrm{Sn}$ & $0.2-6.8$ & 60 & 63 & $1-200$ & 50 \\
$\mathrm{~V}$ & $0.001-1.5$ & $5-10$ & $5-13$ & $3-500$ & $50-100$ \\
$\mathrm{Zn}$ & $1-400$ & $100-400$ & $100-900$ & $1-900$ & $70-400$ \\
\hline $\mathrm{Cb}$ & & & &
\end{tabular}

A: Concentrations above which toxicity is likely.

B: Concentrations likely to cause a $10 \%$ reduction in yield.

Source: Alloway (1995).

MATERIALS AND METHODS

Soil samples were collected from six different locations in composite forms; all within the vicinity of an integrated steel complex and small scale associated companies. All the sites are located in the various towns or communities, not 
far from the integrated steel industry. The towns are Ujevwu (Ujw) (Latitude $5^{\circ} 479044^{\prime} \mathrm{N}$ and longitude $5^{\circ} 770991^{\prime}$ E); Aladja (Alj) (Latitude $5^{\circ}$ $54765^{\prime} \mathrm{N}$ and longitude $5^{\circ} 7478^{\prime}$ E); Ovwian (Ovw) (Latitude $5^{\circ} 507579^{\prime} \mathrm{N}$ and longitude $5^{\circ}$ 787463' E); Ekete Inland (EkI) (Latitude $5^{\circ}$ 493483' $\mathrm{N}$ and longitude $5^{\circ}$ 825236' E); Orhuwhorun (Orh) (Latitude $5^{\circ} 506213^{\prime} \mathrm{N}$ and longitude $5^{\circ} 840600^{\prime}$ E) and Otor-Udu (OtU) (Latitude $5^{\circ} 457641^{\prime} \mathrm{N}$ and Longitude $5^{\circ} 8686^{\prime} \mathrm{E}$ ). In addition, three different crops, mainly edible leaves consumed in these communities, were cultivated for the purpose of this study. They are pumpkin leaf (Telfaira occidentalis), bitter leaf (Vernonia amygdalina) and scent leaf (Occinium gratissimum) [5]. Soil samples collected with clean plastic spoon and leaf samples were kept inside a clean polythene bags and taken to laboratory for digestion.

\section{ANALYTICAL METHODS}

All chemicals used were of analytical grade and were products of Merck Darmstadt GMBH; and Fluka (Riedel-de Haen) GMBH, Germany; M\&B and BDH of England. Soil samples were digested using USEPA Method 3050B [14, 15] for the analyses of heavy metals. 1gm of each composite sample was made wet with some drops of deionised water and to it was added $10.00 \mathrm{~cm}^{3}$ of $\mathrm{HF}$ followed by $5.00 \mathrm{~cm}^{3}$ of $\mathrm{HNO}_{3}$ and $1.00 \mathrm{~cm}^{3}$ of
$\mathrm{HClO}_{4}$. The content was then evaporated to dryness over a water bath. The procedure (HF$\mathrm{HNO}_{3}-\mathrm{HClO}_{4}$ mixture) was repeated until complete digestion was attained. The residue was dissolved with $10.00 \mathrm{~cm}^{3}$ of $4 \mathrm{M} \mathrm{HCl}$, warmed and transferred into a $50.00 \mathrm{~cm}^{3}$ standard volumetric flask. The content was then made to the $50.00 \mathrm{~cm}^{3}$ mark with deionized water. This solution was for elemental analysis.

The leaves samples were also digested using the same method [14, 15]. However, since the leaf samples are softer, less cumbersome process involving this procedure was used. The leaf samples were oven-dried at $100^{\circ} \mathrm{C}$ for one hour, made to ash. To $5.00 \mathrm{gm}$ of ash leaf sample was added $10.00 \mathrm{~cm}^{3}$ of $4 \mathrm{M}$ hydrochloric acid. The content was heated to boil in a $250.00 \mathrm{~cm}^{3}$ pyrex beaker. The resulting mixture was filtered using medium filter paper. The filtrate was then transferred into $50.00 \mathrm{~cm}^{3}$ standard volumetric flask. The content was then made to the $50.00 \mathrm{~cm}^{3}$ mark with deionized water. This solution was for elemental analysis.

Perkin Elmer model 3110 Atomic Absorption Spectrophotometer (AAS) equipped with airacetylene burner was used to determine the heavy metals in the leaf and soil extracts. Heavy metals involved in this study are silver, cadmium, cobalt, chromium, copper and iron.

\section{RESULTS AND DISCUSSION}

Based on the AAS analyses, the following results were obtained for the six sample sites for both the soil and leaf samples and leaf.

Table 2: Heavy Metals Concentration in Soil Samples (in mg/kg) From the Six Sample Sites

\begin{tabular}{|c|c|c|c|c|c|c|c|c|}
\hline $\mathbf{S} / \mathbf{N}$ & $\begin{array}{c}\text { Sample } \\
\text { Site }\end{array}$ & Season & Ag & Cd & Co & $\mathrm{Cr}$ & $\mathrm{Cu}$ & $\mathrm{Fe}$ \\
\hline \multirow{2}{*}{1} & \multirow{2}{*}{ Ujw } & Wet & 0.25 & 0.25 & 24.58 & 30.88 & 6.33 & 299.28 \\
\hline & & Dry & 0.47 & 0.77 & 35.47 & 75.74 & 8.98 & 440.45 \\
\hline \multirow{2}{*}{2} & \multirow{2}{*}{ Alj } & Wet & 0.01 & 0.21 & 5.11 & 0.02 & 3.74 & 153.36 \\
\hline & & Dry & 0.08 & 0.18 & 5.89 & 0.02 & 5.07 & 170.38 \\
\hline \multirow{2}{*}{3} & \multirow{2}{*}{ Ovw } & Wet & 0.06 & 0.17 & 4.97 & 0.02 & 3.66 & 93.98 \\
\hline & & Dry & 0.08 & 0.21 & 5.77 & 0.02 & 5.77 & 153.66 \\
\hline \multirow{2}{*}{4} & \multirow{2}{*}{ EkI } & Wet & 0.03 & 0.31 & 4.57 & 0.02 & 3.44 & 94.52 \\
\hline & & Dry & 0.05 & 0.22 & 5.02 & 0.02 & 6.77 & 170.38 \\
\hline \multirow{2}{*}{5} & \multirow{2}{*}{ Orh } & Wet & 0.08 & 0.32 & 4.75 & 0.02 & 3.77 & 100.24 \\
\hline & & Dry & 0.12 & 0.22 & 5.12 & 0.02 & 5.57 & 116.24 \\
\hline \multirow{2}{*}{6} & \multirow{2}{*}{ OtU } & Wet & 0.02 & 0.23 & 3.98 & 0.02 & 1.75 & 72.55 \\
\hline & & Dry & 0.02 & 0.31 & 4.54 & 0.02 & 4.24 & 80.27 \\
\hline
\end{tabular}


Table 3: Heavy Metals Concentration in Leaf Samples (in mg/kg) Collected From Ujevwu Sample Site

\begin{tabular}{ccccccccc}
\hline S/N & Plant & Season & Ag & Cd & Co & Cr & Cu & Fe \\
\hline \multirow{2}{*}{1} & \multirow{2}{*}{ Bitter Leaf } & Wet & 13.21 & 43.44 & 2.63 & 21.43 & 561.64 & 2062.42 \\
& & Dry & 11.23 & 27.25 & 2.23 & 19.22 & 212.81 & 1744.65 \\
\multirow{2}{*}{2} & Pumpkin & Wet & 15.45 & 78.47 & 4.44 & 18.44 & 384.86 & 3535.42 \\
& \multirow{2}{*}{ Leaf } & Dry & 14.43 & 47.25 & 3.47 & 13.21 & 285.63 & 2913.63 \\
\multirow{2}{*}{3} & \multirow{2}{*}{ Scent Leaf } & Wet & 16.83 & 45.62 & 3.67 & 22.87 & 197.21 & 1102.52 \\
& & Dry & 15.26 & 17.24 & 3.33 & 13.22 & 131.24 & 720.68 \\
\hline
\end{tabular}

Table 4: Heavy Metals Concentration in Leaf Samples (in mg/kg) Collected From Aladja Sample Site

\begin{tabular}{ccccccccc}
\hline S/N & Plant & Season & Ag & Cd & Co & Cr & Cu & Fe \\
\hline \multirow{2}{*}{1} & \multirow{2}{*}{ Bitter Leaf } & Wet & 1.15 & 21.63 & 1.44 & 10.63 & 320.83 & 662.52 \\
& & Dry & 0.24 & 20.47 & 1.24 & 9.25 & 106.41 & 1758.64 \\
\multirow{2}{*}{2} & \multirow{2}{*}{ Pumpkin Leaf } & Wet & 2.45 & 49.25 & 2.26 & 9.24 & 242.42 & 1157.12 \\
& & Dry & 1.43 & 33.64 & 1.83 & 6.64 & 142.82 & 771.44 \\
\multirow{2}{*}{3} & \multirow{2}{*}{ Scent Leaf } & Wet & 3.83 & 22.83 & 1.62 & 13.44 & 98.42 & 1114.54 \\
& & Dry & 2.62 & 8.44 & 0.59 & 6.65 & 65.69 & 656.71 \\
\hline
\end{tabular}

Table 5: Heavy Metals Concentration in Leaf Samples (in mg/kg) Collected From Ovwian Sample Site

\begin{tabular}{ccccccccc}
\hline S/N & Plant & Season & Ag & Cd & Co & Cr & Cu & Fe \\
\hline \multirow{2}{*}{1} & \multirow{2}{*}{ Bitter Leaf } & Wet & 2.45 & 27.62 & 1.24 & 8.62 & 272.86 & 557.54 \\
& & Dry & 0.63 & 19.44 & 0.84 & 7.42 & 58.46 & 1583.61 \\
\multirow{2}{*}{2} & \multirow{2}{*}{ Pumpkin Leaf } & Wet & 4.62 & 45.23 & 1.64 & 7.63 & 194.42 & 3451.54 \\
& \multirow{2}{*}{3} & Dry & 3.37 & 21.12 & 0.64 & 4.61 & 114.85 & 2368.66 \\
& & Wet & 7.82 & 19.62 & 1.17 & 9.08 & 69.11 & 997.54 \\
& & Dry & 5.44 & 8.47 & 0.27 & 4.64 & 24.81 & 645.63 \\
\hline
\end{tabular}

Table 6: Heavy Metals Concentration in Leaf Samples (in mg/kg) Collected From Ekete Inland Sample Site

\begin{tabular}{|c|c|c|c|c|c|c|c|c|}
\hline $\mathbf{S} / \mathbf{N}$ & Plant & Season & Ag & Cd & Co & $\mathrm{Cr}$ & $\mathrm{Cu}$ & $\mathbf{F e}$ \\
\hline \multirow{2}{*}{1} & \multirow{2}{*}{ Bitter Leaf } & Wet & 1.14 & 20.29 & 0.44 & 10.67 & 245.64 & 557.53 \\
\hline & & Dry & 0.42 & 13.47 & 0.41 & 8.44 & 144.44 & 706.91 \\
\hline \multirow{2}{*}{2} & \multirow{2}{*}{ Pumpkin Leaf } & Wet & 0.83 & 13.18 & 0.64 & 8.41 & 175.12 & 817.23 \\
\hline & & Dry & 0.45 & 20.28 & 0.47 & 7.25 & 103.44 & 534.94 \\
\hline \multirow{2}{*}{3} & \multirow{2}{*}{ Scent Leaf } & Wet & 1.44 & 17.17 & 0.42 & 8.25 & 83.21 & 798.73 \\
\hline & & Dry & 0.45 & 6.63 & 0.44 & 3.82 & 142.44 & 516.54 \\
\hline
\end{tabular}


Table 7: Heavy Metals Concentration in Leaf Samples (in mg/kg) Collected From Orhuwhorun Sample Site

\begin{tabular}{rlccccccc}
\hline S/N & \multicolumn{1}{c}{ Plant } & Season & Ag & Cd & Co & Cr & Cu & Fe \\
\hline \multirow{2}{*}{1} & \multirow{2}{*}{ Bitter Leaf } & Wet & 0.81 & 19.53 & 0.43 & 9.07 & 279.64 & 461.83 \\
& & Dry & 0.24 & 17.42 & 0.22 & 7.62 & 107.41 & 833.73 \\
\multirow{2}{*}{2} & \multirow{2}{*}{$\begin{array}{l}\text { Pumpkin } \\
\text { Leaf }\end{array}$} & Wet & 1.24 & 46.81 & 1.17 & 7.82 & 211.22 & 532.11 \\
\multirow{2}{*}{3} & \multirow{2}{*}{ Scent Leaf } & Dry & 0.47 & 31.19 & 0.63 & 4.83 & 123.61 & 334.93 \\
& & Wet & 3.66 & 19.84 & 0.64 & 9.84 & 45.42 & 725.63 \\
& & Dry & 1.63 & 7.15 & 0.24 & 5.43 & 77.43 & 519.12 \\
\hline
\end{tabular}

Table 8: Heavy Metals Concentration in Leaf Samples (in mg/kg) Collected From Otor-Udu Sample Site

\begin{tabular}{ccccccccc}
\hline S/N & Plant & Season & Ag & Cd & Co & Cr & Cu & Fe \\
\hline \multirow{2}{*}{1} & \multirow{2}{*}{ Bitter Leaf } & Wet & 1.54 & 19.21 & 0.43 & 9.11 & 19.61 & 369.47 \\
& & Dry & 0.44 & 13.43 & 0.23 & 6.64 & 7.62 & 666.97 \\
\multirow{2}{*}{2} & \multirow{2}{*}{ Pumpkin Leaf } & Wet & 1.65 & 11.07 & 1.11 & 7.84 & 14.83 & 495.72 \\
& & Dry & 1.35 & 19.44 & 0.63 & 6.63 & 8.62 & 267.91 \\
\multirow{2}{*}{3} & \multirow{2}{*}{ Scent Leaf } & Wet & 1.63 & 17.21 & 0.61 & 9.21 & 3.25 & 620.54 \\
& & Dry & 0.87 & 9.83 & 0.28 & 4.43 & 5.44 & 415.32 \\
\hline
\end{tabular}

The transfer factor (TF) was determined using the ratio of total heavy metal values obtained for both soil and plant, based on the formula for its calculation [16] as explained below:

$$
\mathrm{TF}=\frac{\operatorname{Ps}(\mu \mathrm{g} / \mathrm{g} \text { dry weight })}{\mathrm{Sr}(\mu \mathrm{g} / \mathrm{g} \text { dry weight })}
$$

where $\mathrm{Ps}=$ Total plant metal content originating from the plant analysis

$\mathrm{Sr}=$ Total metal content in soil analysis

Table 9: Transfer Factor Obtained for the Six Sample Sites

\begin{tabular}{lccccccc}
\hline \multicolumn{1}{c}{ Sample Site } & Season & $\mathbf{A g}$ & $\mathbf{C d}$ & $\mathbf{C o}$ & $\mathbf{C r}$ & $\mathbf{C u}$ & $\mathbf{F e}$ \\
\hline \multirow{3}{*}{ Ujw } & Wet & 196.45 & 212.79 & 0.46 & 3.37 & 102.95 & 14.40 \\
& Dry & 95.08 & 91.53 & 0.14 & 1.01 & 49.26 & 6.67 \\
Ala & Wet & 41.03 & 120.58 & 0.23 & 1.78 & 58.40 & 15.16 \\
& Dry & 11.95 & 54.24 & 0.06 & 0.51 & 28.88 & 8.01 \\
Ovw & Wet & 60.88 & 112.62 & 0.17 & 1.40 & 47.02 & 11.59 \\
& Dry & 27.61 & 50.79 & 0.05 & 0.37 & 21.76 & 5.67 \\
EkI & Wet & 15.58 & 73.35 & 0.06 & 1.50 & 42.26 & 6.09 \\
& Dry & 4.48 & 44.52 & 0.04 & 0.41 & 27.05 & 3.38 \\
Orh & Wet & 24.89 & 106.72 & 0.10 & 1.43 & 46.98 & 4.96 \\
& Dry & 8.32 & 50.82 & 0.03 & 0.38 & 27.99 & 2.85 \\
OtU & Wet & 24.83 & 80.36 & 0.08 & 1.40 & 3.40 & 4.22 \\
& Dry & 7.65 & 45.73 & 0.04 & 0.38 & 2.01 & 2.40 \\
\hline
\end{tabular}

From the data obtained, it is obvious that the heavy metal contents in the leaf samples are higher compared to the heavy metal contents in soil samples. In some cases, they are twice or 
more. Ujevwu result shows that concentration values for dry season are higher than those obtained for wet season in soil samples, while in leaf samples, it is in the opposite; in which the concentration values are higher for wet season compare to dry season. Iron has the highest total concentration values, with silver and cadmium been the least. The elevated or upper limit for iron in soil samples is $299.28 \mu \mathrm{g} / \mathrm{g}$ while silver and cadmium is $.25 \mu \mathrm{g} / \mathrm{g}$. For the leaf samples from the same site, pumpkin (Telfaira occidentalis) had $3535.42 \mu \mathrm{g} / \mathrm{g}$ for wet season and $2913.63 \mu \mathrm{g} / \mathrm{g}$ for dry season; bitter leaf (Vernonia amygdalina) had $2062.42 \mu \mathrm{g} / \mathrm{g}$ for wet season and $1744.65 \mu \mathrm{g} / \mathrm{g}$ for dry season; and scent leaf (Occinium gratissimum) at the same sample site had $1102.52 \mu \mathrm{g} / \mathrm{g}$ for wet season and $720.68 \mu \mathrm{g} / \mathrm{g}$ for dry season. Silver had lower concentration for both wet and dry season. Furthermore, the values for wet season are higher than those for dry season for all the heavy metals. The values obtained for transfer factor shows higher values for cadmium and silver with cobalt and chromium having lower values, especially for wet season when there is easy flow of salt solution; and in the order: $\mathrm{Cd}>\mathrm{Ag}>\mathrm{Cu}>\mathrm{Fe}>$ $\mathrm{Cr}>\mathrm{Co}$. This indicates some level of toxicity, which need to be controlled so as to prevent danger in the future. All the results follow the same trend and is consistent with the findings of some researchers $[1,17,18,19,20]$.

Aladja result indicated higher level of total concentration of iron for both wet and dry season with higher values in dry season; while silver values were lower. All the heavy metals follow the same pattern. The result shows consistency for other heavy metals under investigation with dry season been greater than wet season. The values for wet season for iron is $153.36 \mu \mathrm{g} / \mathrm{g}$ while for dry season is $170.38 \mu \mathrm{g} / \mathrm{g}$. Silver for wet and dry season 0.01 and $0.08 \mu \mathrm{g} / \mathrm{g}$ respectively; with other heavy metals having values between iron and silver. The concentration of heavy metals in soil samples is in the order: $\mathrm{Fe}>\mathrm{Co}>\mathrm{Cu}>\mathrm{Cd}>\mathrm{Ag}>$ $\mathrm{Cr}$. The iron in the leaf samples of pumpkin (Telfaira occidentalis) had $1157.12 \mu \mathrm{g} / \mathrm{g}$ for wet season and $771.44 \mu \mathrm{g} / \mathrm{g}$ for dry season; bitter leaf (Vernonia amygdalina) had $662.52 \mu \mathrm{g} / \mathrm{g}$ for wet season and $1758.64 \mu \mathrm{g} / \mathrm{g}$ for dry season; and scent leaf (Occinium gratissimum) had $1114.54 \mu \mathrm{g} / \mathrm{g}$ for wet season and $656.71 \mu \mathrm{g} / \mathrm{g}$ for dry season. Values obtained for transfer factor for Aladja samples shows higher values for cadmium and copper with cobalt and chromium been low; and it were higher for wet season for all the heavy metals. This is probably because mobility is higher in wet season compare to dry season. The transfer factor is in the order: $\mathrm{Cd}>\mathrm{Cu}>\mathrm{Ag}>\mathrm{Fe}>\mathrm{Cr}>\mathrm{Co}$. This indicates some level of toxicity, which need to be controlled so as to prevent danger in the future. All the results follow the same trend and is consistent with the findings of some researchers $[1,17,18,19,20]$.

Ovwian result also indicated higher, but moderate level of total concentration of iron for both wet and dry season with dry season having higher values. Chromium values were lower at this site, but following the same pattern for iron. The result shows the same consistency for other heavy metals under investigation. The values for wet season for iron is $93.98 \mu \mathrm{g} / \mathrm{g}$ while for dry season is $153.66 \mu \mathrm{g} / \mathrm{g}$. Chromium for wet and dry season $0.02 \mu \mathrm{g} / \mathrm{g}$. Other heavy metals values are in between iron and chromium. The concentration of heavy metals in soil samples is in the order: $\mathrm{Fe}>$ $\mathrm{Cu}>\mathrm{Co}>\mathrm{Cd}>\mathrm{Ag}>\mathrm{Cr}$. The iron concentration for the leaf samples of pumpkin (Telfaira occidentalis) had $3451.54 \mu \mathrm{g} / \mathrm{g}$ for wet season and $2368.66 \mu \mathrm{g} / \mathrm{g}$ for dry season; bitter leaf (Vernonia amygdalina) had $557.54 \mu \mathrm{g} / \mathrm{g}$ for wet season and $11583.61 \mu \mathrm{g} / \mathrm{g}$ for dry season; and scent leaf (Occinium gratissimum) had $997.54 \mu \mathrm{g} / \mathrm{g}$ for wet season and $645.63 \mu \mathrm{g} / \mathrm{g}$ for dry season. Transfer factor values for Ovwian samples were higher for cadmium and silver while cobalt and chromium have lower values. It is higher for wet season for all the heavy metals, which shows consistency with other results obtained for other sites. The transfer factor is in the order: $\mathrm{Cd}>\mathrm{Ag}>\mathrm{Cu}>\mathrm{Fe}$ $>\mathrm{Cr}>\mathrm{Co}$. There is an indication that some level of toxicity, which need to be controlled so as to prevent danger in the future. All the results follow the same trend and is consistent with the findings of some researchers $[1,17,18,19,20]$.

Ekete Inland result also revealed higher, but moderate level of total concentration of iron for both wet and dry season with dry season having higher values. Chromium values were lower at this site, but following the same pattern for iron. The result shows the same consistency for other heavy metals under investigation. The values for wet season for iron is $94.52 \mu \mathrm{g} / \mathrm{g}$ while for dry season is $170.38 \mu \mathrm{g} / \mathrm{g}$. Chromium for wet and dry 
season is $0.02 \mu \mathrm{g} / \mathrm{g}$ in both cases; with other heavy metals having values between iron and chromium. The concentration of heavy metals in soil samples is in the order: $\mathrm{Fe}>\mathrm{Co}>\mathrm{Cu}>\mathrm{Ag}>\mathrm{Cd}>\mathrm{Cr}$. For the leaf samples, pumpkin leaf (Telfaira occidentalis) had $817.23 \mu \mathrm{g} / \mathrm{g}$ for wet season and $534.94 \mu \mathrm{g} / \mathrm{g}$ for dry season; bitter leaf (Vernonia amygdalina) had $557.53 \mu \mathrm{g} / \mathrm{g}$ for wet season and $706.91 \mu \mathrm{g} / \mathrm{g}$ for dry season; and scent leaf (Occinium gratissimum) had $798.73 \mu \mathrm{g} / \mathrm{g}$ for wet season and $516.54 \mu \mathrm{g} / \mathrm{g}$ for dry season. Values obtained for transfer factor for Ekete Inland samples shows higher values for cadmium and copper with cobalt and chromium having lower values; and it is higher for wet season for all the heavy metals, which shows consistency with other results obtained for other sites. The transfer factor is in the order: $\mathrm{Cd}>\mathrm{Cu}>\mathrm{Ag}>\mathrm{Fe}>\mathrm{Cr}>\mathrm{Co}$. This indicates some level of toxicity, which need to be controlled so as to prevent danger in the future. All the results follow the same trend and is consistent with the findings of some researchers $[1,17,18,19,20]$.

Orhuwhorun result also revealed higher, but moderate level of total concentration of heavy metals. Even though the values obtained are lower compare to other sites, especially those that ate close to the industrial processing area. Iron concentration for both wet and dry season had higher values. Chromium and silver had lower value. The result shows the same consistency for other heavy metals under investigation. The values for wet season for iron is $100.24 \mu \mathrm{g} / \mathrm{g}$ while for dry season is $116.24 \mu \mathrm{g} / \mathrm{g}$. Chromium is $0.02 \mu \mathrm{g} / \mathrm{g}$ for both wet and dry season; with other heavy metals having values falling in between iron and chromium. The concentration of heavy metals in soil samples is in the order: $\mathrm{Fe}>\mathrm{Co}>\mathrm{Cu}>\mathrm{Cd}>$ $\mathrm{Ag}>\mathrm{Cr}$. For the leaf samples, pumpkin leaf (Telfaira occidentalis) had $542.11 \mu \mathrm{g} / \mathrm{g}$ for wet season and $334.93 \mu \mathrm{g} / \mathrm{g}$ for dry season; bitter leaf (Vernonia amygdalina) had $461.83 \mu \mathrm{g} / \mathrm{g}$ for wet season and $833.73 \mu \mathrm{g} / \mathrm{g}$ for dry season; and scent leaf (Occinium gratissimum) had $725.63 \mu \mathrm{g} / \mathrm{g}$ for wet season and $519.12 \mu \mathrm{g} / \mathrm{g}$ for dry season. Values obtained for transfer factor for Orhuwhorun samples indicates higher quantity for cadmium and copper and lower for chromium and cobalt. All values are higher for wet season compare to dry season. This shows consistency with other results obtained for other sites. The transfer factor is in the order: $\mathrm{Cd}>\mathrm{Cu}>\mathrm{Ag}>\mathrm{Fe}>\mathrm{Cr}>\mathrm{Co}$. Some level of toxicity was observed from the values obtained, which need to be controlled so as to prevent danger in the future. All the results follow the same trend and is consistent with the findings of some researchers $[1,17,18,19,20]$.

Otor-Udu had values are relatively low when compared to the other five sites. This is because of its distance from the industrial complex with reference to other sample sites. Values obtained are higher, but very moderate. Total heavy metals concentration at this site is higher for iron for both wet and dry season, Chromium and silver values were lower for both seasons. The result shows the same consistency for other heavy metals under investigation. The heavy metals distribution also shows iron as the predominant heavy metal compare to others. The values for wet season for iron is $72.55 \mu \mathrm{g} / \mathrm{g}$ while for dry season is 80.27 $\mu \mathrm{g} / \mathrm{g}$. Chromium and silver value is $0.02 \mu \mathrm{g} / \mathrm{g}$ for both wet and dry season. Other heavy metals have values in between these other heavy metals. The concentration of heavy metals in soil samples is in the order: $\mathrm{Fe}>\mathrm{Co}>\mathrm{Cu}>\mathrm{Cd}>\mathrm{Ag}, \mathrm{Cr}$. For the leaf samples, pumpkin leaf (Telfaira occidentalis) had $495.72 \mu \mathrm{g} / \mathrm{g}$ for wet season and $276.91 \mu \mathrm{g} / \mathrm{g}$ for dry season; bitter leaf (Vernonia amygdalina) had $369.47 \mu \mathrm{g} / \mathrm{g}$ for wet season and $666.97 \mu \mathrm{g} / \mathrm{g}$ for dry season; and scent leaf (Occinium gratissimum) had $620.54 \mu \mathrm{g} / \mathrm{g}$ for wet season and $415.32 \mu \mathrm{g} / \mathrm{g}$ for dry season. Values obtained for transfer factor for Otor-Udu samples shows higher values for cadmium and silver with cobalt having lower values; and it is higher for wet season for all the heavy metals, which shows consistency with other results obtained for other sites. The transfer factor is in the order: $\mathrm{Cd}>\mathrm{Ag}>\mathrm{Fe}>\mathrm{Cu}>\mathrm{Cr}>$ Co. This indicates some level of toxicity, which need to be controlled so as to prevent danger in the future. All the results follow the same trend and is consistent with the findings of some researchers $[1,17,18,19,20]$.

\section{CONCLUSION}

Based on these results obtained, the total heavy metals concentration is in the order $\mathrm{Fe}>\mathrm{Cr}>\mathrm{Co}$ $>\mathrm{Cu}>\mathrm{Cd}>\mathrm{Ag}$ for soil samples; while for leaf samples, it is in the order $\mathrm{Fe}>\mathrm{Cu}>\mathrm{Cd}>\mathrm{Cr}>\mathrm{Co}$ $>\mathrm{Ag}$. The transfer factor (TF) is in the order $\mathrm{Cd}>$ $\mathrm{Ag}>\mathrm{Cu}>\mathrm{Fe}>\mathrm{Cr}>\mathrm{Co}$. Some heavy metals are important for human and plant survival, but in 
minute quantity, hence the name micronutrients. This shows that when their consumption is beyond certain quantities, then they become hazardous or dangerous to the system. It is obvious that some heavy metals, even when they are regarded as important micronutrient, can be very harmful when it exceeds the normal required or extreme level, hence the need to control the uptake. From this study, it is obvious that the transfer factor for cadmium, silver and copper are so high to the extent that they can cause health problem for inhabitants in the future. If the negative effects has not manifest on these plants, then it is just a time bomb waiting to explode. However, this can still be controlled before the plants become totally contaminated in such a way that finding remedy would take a lot of processes. The toxicity of these heavy metals to plants, humans and other living things can be devastating and needs attention especially now that the uptake can be controlled.

\section{REFERENCES}

1. B. J. Alloway (1995). Soil Processes and the Behaviour of Heavy Metals. -In Heavy Metals in Soils.2nd Edition (B. J. Alloway Ed.). Blackie, New York, USA.11 - 37.

2. Analytical Methods for Flame Spectroscopy. (1979). Publication No. 85-100009-10 Varian Tectron Pty. Ltd., Springvale, Australia., 10 - 65 .

3. U. A. Awode, M. I. Balarabe, O. J. Okunola and S. G. Adewusi (2008). Levels of some trace metals in the fadama soils and pepper (Capsicum annum)along the bank of River

Challawa, Nigeria. Asian J. Sci. Res.ISSN 1992 - 1454. 1 - 6.

4. T. M. Chiroma, F. K. Hymore and R. O. Ebawele (2003). Heavy metal contamination of vegetables and soils irrigated with sewage water in Yola. NJERD., 2(3): 25- 31.

5. A. C. Dutta (2009). Botany for Degree Students.36th Edition. Sai Printopack Printers and

Published by Oxford University Press, YMCA Library Building, Jai Singh Road, New Delhi 110001, India. 220 - 527.

6. S. H. O. Egboh, G. E. Nwajei and E. O. Adaikpoh (2002). Selected heavy metals concentration in sediments from major gutters in Warri, Delta State of Nigeria.Nig. Journal of Sc. and Environ., 2: $105-111$.

7. E. M. Emeshili and S. H. O. Egboh (2008). Levels of heavy metals in Ucapagilator and

Drepane africana from Ase River, SouthSouth Nigeria. J. Chem. Soc. of Nig., 33 (2): 148-151.

8. R. S. Lokeshwari and G. T. Chandrappa (2006). Impact of heavy metal contamination of

Bellander Lake on soil and cultivated vegetation. Current Science, 5: 622-627.

9. C. L. Ndiokwere (1985). "The disposal of arsenic, chromium and copper from a wood

treatment factory and their effect on soil, vegetation and crops". Intern. Journal

Environ. Studies, 24: 231-234.

10. S. A. Osakwe (2009). Heavy metal distribution and biodiversity in soils and cassava

(Manihot esculenta Grantz) along WarriAbraka Expressway, Delta State, Nigeria. J.

Chem. Soc. of Nig., 34 (1): 211-217.

11. B. O. Peretiemo-Clarke, M. A. Balogun and O. A. Akpojiyovwi, O. A. (2009). A study of

physicochemical characteristics of Ugborikoko/Okere stream as an index of pollution.

African Journal of Biotechnol., 8 (22): 6272-6276.

12. L. Zhenil, E. Y. Xlaoe and J. S. Peter (2005). Trace elements in agrosystems and impact on

the environment. J. of Trace Elements in Medicine and Biology, 19: 125-140.

13. M. A. Balogun, M. O. Money, H. N. Omosigho

and H. O. Ataikiru (2019). Pollution level determination using chemical speciation in the vicinity of petroleum prospecting areas in Southern Niger Delta. J. Chem. Soc. of Nig., 44 (5): $686-692$.

14. M. Radojevic and N. V. Bashkin (1999). Practical Environmental Analysis. Royal Society of

Chemistry. Thomas Grahams House, Cambridge, UK. 180-430.

15. USEPA (1996). Acid digestion of sediments, sludge and soils: Method 305B. USEPA; 
Washington D.C., USA. 5 - 15.

16. R. M. Harrison and M. B. Chirgawi (1989). The assessment of air and soil as contributors of

some trace metals to vegetable plants. Use of a filtered air growth cabinet. Sci. Total

Environ., 83: 13-34.

17. N. Mirechi, R. Agie, L. Sunic, L. Milenkovic and Z. Ilic (2015). Transfer factor as indicator of heavy metals contents in plant. Fresenius Enviromental Bulletin. 24 (11c): 4212 - 4219.

18. K. Mwkut and D. Arundhuti (2012). Uptake of metals by four commonly available plants spices collected from crude oil contaminated sites at Lakowa oil field. International Journal of Agric. Sc. And Research. 2 (4): 121 - 134.

19. A. Smical, V. Hotea, V. Oros, J. Juhasz and E. Pop (2008). Studies on transfer and bioaccumulation of heavy metals from soil into lettuce. Environmental Engineering and Management Journal. 7 (5): 609 - 615.

20. Z. I. Yashim, O. K. Israel and M. Hannatu (2014). A study of the uptake of heavy metals by plants

near metal-scrape dumpsite in Zaria, Nigeria. Journal of Applied Chemistry. Vol. 2014

Article 394650. 